\title{
УЛААНБААТАР ХОТ: ТӨВЛӨРӨЛ БА АСУУДАЛ
}

\author{
О.Баасантогтох \\ ШУА-ийн ФСЭХ-ийн ЭШДэА \\ Цахим шуудан: оуи_baasan@yahoo.com
}

\begin{abstract}
Aim of the paper is to investigate migration flow, a reasons for migration, regions and places of migrations, types of migrations based on the statistical data and data of sociological survey "Urbanization process in Mongolia" conducted by the Department of Sociology, IPSL in 2012.
\end{abstract}

ТүлхүҮр Үг: Хотжилт, иилжсих хөдөлгөөн, суурьшльн бүс, нийгэм, экологи, амьдралын хэв маяг, нягтрал, соёл, зан суртахуун.

\section{Хотын хүн амын бүрдүҮлэгчид}

Дэлхийн хотуудын хүн амын өсөлтийн талаар АНУ-ын эрдэмтэн Жон Пэйлэн “1790 оны тооллогод үзүүлснээр шинэ улсын хамгийн том хот болох Нью-Йорк 33000 оршин суугчтай байсан. Хоёр дахь том хот болох Филаделфи 28000 хүнтэй байсан. Хорин жилийн дараа Нью-Йорк 100.000 мянга гаруй хүнтэй болсон байв. Хувьсгалын дайны дараах хотуудын ийм эрс өсөлтөд зөвхөн гадаадын цагаачид болон хөдөөгийн шилжин ирэгсэдийн өсөлт бус: уугуул хүмүүсийн өсөлт онцгой үүрэг гүйцэтгэсэн.” [2. 75] хэмээн 224 жилийн өмнөх Нью-Йорк хотын хүн амын өсөлтөд уугуул иргэдээс гадна гадаадын цагаач иргэд, хөдөөгийн шилжин ирэгсэд зонхилох нөлөө үзүүлж байсан талаар тэмдэглэсэн байдаг. Одоогийн дэлхий ертөнцөд ч хот суурин руу чиглэсэн шилжих хөдөлгөөний урсгал тасралтгүй үргэлжилж байна. Жон Пэйлэн “The urban world” бүтээлдээ 2020 он гэхэд 1995 онтой харьцуулахад хөдөөгийн хүн ам 17 орчим хувиар буурч том хотын хүн ам 10 гаруй хувиар нэмэгдэнэ гэж тооцсон байна. Түүний тэмдэглэсэнчлэн дэлхий дахинд хотжих үйл явц тасралтгүй, эрчимтэй явагдаж байгаа бөгөөд шилжин ирэгсэд голлох нөлөө үзүүлж байна.

Манай улсад ялангуяа Улаанбаатар хотод шилжин ирэгсдийн тоо суурин хүн амын цэвэр өсөлтөөс илүү гарч байгаа юм. Энэ үйл явцын талаар социологич, доктор (Sc.D) Х.Гүндсамбуу «... хотын хүн ам өөрийнхөө гэхээсээ хөдөөний хүн амын, бас гаднаас цагаачлан ирэгчдийн тооцоон дээр голлон өсөх болно» [1. 523] гэж тэмдэглэсэн байдаг. Тухайлан хэлбэл, ардчилсан нийгэмд шилжих үетэй зэрэгцэн хот, суурин руу чиглэсэн шилжих хөдөлгөөний урсгал эрчимжсэн. Ойрын ирээдүйд ч Улаанбаатар хотын хүн амын өсөлтөд шилжин ирэгсэд тогтвортой нөлөөлсөөр байх хандлагатай байна. Энэ нь Улаанбаатар хотод боловсрол, эрүүл мэнд, эдийн засаг, дэд бүтэц, төрийн удирдлага, соёлын г.м нийгмийн татах хүчний хэт $u x$ төвлөрөл бий болсонтой холбоотой юм. Тухайлбал, 2012 оны байдлаар, Улаанбаатар хот нь тус улсын нийт нутаг дэвсгэрийн 0.3 хувийг эзэлдэг ч 2012 оны байдлаар:

- ДНБ-ний $62 \%$,

- ААНБ-ын 63.8\%,

- Боловсруулах үйлдвэрийн 50\%,

- Барилга угсралтын 95.7\%, 
- ИДС-ийн $88.5 \%$,

- Нийт оюутны $95.3 \%$ нь тус тус төвлөрч байна.

Эдгээр хүчин зүйлээс үүдэлтэй хотын хүн амын өсөлт нэмэгдэх болсон.

\section{Социологийн болон статистикийн} судалгааны үр дүнгээс сийрүүлэн харвал: өнөөдөр Улаанбаатар хотын хүн амын 52 хувийг [6. 41; 7. 16] шилжин ирэгсэд эзлэж байгаа юм.

Хүснэгт 1. Хотын хүн амын өсөлт дэх механик хүчин зүйлийн нөлөө

\begin{tabular}{|c|l|c|c|c|}
\hline \multirow{2}{*}{ № } & & \multicolumn{3}{|c|}{ Улаанбаатар } \\
\cline { 3 - 5 } & & 2000 & 2010 & Өсөлт \\
\hline 1 & Төрсөнөөс хойш оршин сууж байгаа & 491089 & 544813 & 9.8 \\
\hline 2 & Шилжиж ирсэн хүн ам & 268988 & 590399 & 54.4 \\
\hline 3 & Шилжиж явсан хүн ам & 35146 & 46755 & 24.8 \\
\hline 4 & Хүн амын өсөлт & 35.3 & 52.0 & \\
\hline
\end{tabular}

Хүн ам, орон сууцны 2000, 2010 оны улсын тооллогын мэдээлэлд үндэслэн арван жилийн үечлэлээр шилжих хөдөлгөөний эрчим, идэвхжлийг харьцуулан харахад Улаанбаатар хот руу чиглэсэн шилжих хөдөлгөөний урсгал сүүлийн 10 жилийн дотор өмнөх үеэс 54.4 хувиар нэмэгдсэн байхад Улаанбаатар хотод төрсөн уугуул оршин суугчид 9.8 хувиар нэмэгдсэн байна (Төрснөөс хойших шилжих хөдөлгөөний
Үндсэн агуулга нь аймаг, нийслэлийн нутаг дэвсгэрт байнга оршин суугаа хүн амын хэдэн хувь нь уугуул нутагтаа амьдарч байгааг илэрхийлэхэд оршино. Энэхүу мэдээллийг ашиглахад дутагдалтай тал нь шилжсих хөдөлгөөнд оролисон хугацаа тодорхой бус байдаг) [7. 78]. Өөрөөр хэлбэл, хотын хүн ам шилжин ирэгсдийн урсгалаар сэлбэгдэж байна.

ХУснэгт 2. Хотод иилжиж ирсэн хугацаа

\begin{tabular}{|c|l|c|}
\hline № & \multicolumn{1}{|c|}{ Улаанбаатар } \\
\hline 1 & 5 хүртэл жил & 23.0 \\
\hline 2 & $6-10$ жил & 26.5 \\
\hline$\sum$ & $1+2$ & 49.4 \\
\hline 3 & $11-20$ жил & 34.1 \\
\hline$\sum$ & $1+2$ & 83.5 \\
\hline 4 & $21-30$ жил & 6.1 \\
\hline 5 & $31-40$ жил & 5.7 \\
\hline 6 & $41-50$ жил & 2.8 \\
\hline 7 & 51-ээс дээш жил & 23.0 \\
\hline
\end{tabular}

“Монгол дахь хотжих үйл явц” сэдэвт социологийн судалгааны үр дүнгээс дээрх үр дүнг бататган харж болох бөгөөд Улаанбаатар хотоос судалгаанд хамрагдсан иргэдийн 83.5 хувь нь сүүлийн 20 жилийн дотор шилжиж ирсэнээс 49.4 хувь нь 2000 оноос хойш Улаанбаатар хотод суурьшсан байна. Харин хөдөлгөөнд оролцогсдын дунд 15-29 хүртэл насны залуучууд, хүйсийн хувьд энэ насны эмэгтэйчүүд давамгайлах хандлагай байна. Энэ нь хүн амын бүтцийн хувьд Улаанбаатар хот нь залуу хотод тооцогдох хандлагатай байгааг илэрхийлж байна. 
Хүснэгт 3. 2010 онд шилюсих хөдөлгөөнд оролиогсод нас, хүйсийн бүтиээр [7. 85] (Насаар бүлэглэсэн $\partial)$

\begin{tabular}{|c|c|c|c|c|c|c|}
\hline \multirow{2}{*}{$\begin{array}{c}\text { Насны } \\
\text { бүлэг }\end{array}$} & \multicolumn{3}{|c|}{ Бүгд } & \multicolumn{2}{c|}{ Шилжигсэд } \\
\cline { 2 - 7 } & Хүний тоо & $\begin{array}{c}\text { Дунд эзлэх } \\
\text { хувь }\end{array}$ & Хүний тоо & $\begin{array}{c}\text { Дунд эзлэх } \\
\text { хувь }\end{array}$ & Хүний тоо & $\begin{array}{c}\text { Дунд эзлэх } \\
\text { хувь }\end{array}$ \\
\hline & 114.022 & 100 & 60.953 & 100 & 53.069 & 100 \\
\hline $0-14$ & 18733 & 16,4 & 9530 & 15,6 & 9203 & 17,3 \\
\hline $15-29$ & 60870 & 53,4 & 18956 & 50,7 & 29998 & 56,5 \\
\hline $30+$ & 34419 & 30,1 & 20551 & 33,7 & 13868 & 26,1 \\
\hline
\end{tabular}

Шилжиххөдлөгөөндоролцогсдындунд залуучууд давамгайлж байгаа нь тэдний нийгэм, эдийн засаг, оюуны хэрэгцээтэй холбоотой юм. "Монголын нийгмийн өөрчлөлт” сэдэвт бүтээлд эрэгтэйчүҮдийн 21.4 хувь, эмэгтэйчүудийн 34.3 хувь нь боловсрол эзэмиихээр ирж байна [8. 165] гэж тэмдэглэсэн лугаа залуучуудын олонх нь мэргэжилтэй болохоор Улаанбаатар хотод ирдэг. Харин бусад бүлгийнхэн амьжиргаагаа дээшлүүлэх (44.5\%: Үүнд, амьжиргаа хөөж 21.9 хувь, ажил хайж 14.1 хувь, орон сууц, ахуйн нөхцлөө сайжруулахаар 8.5 хувь) шаардлагаар хотод шилжин суурьших нь түгээмэл байна.

График 1. Улаанбаатар хотод шилжин ирсэн шалтгаан

\begin{tabular}{|c|c|}
\hline $\begin{array}{r}\text { Юм юмандаа ойртсон } \\
\text { Бусад }\end{array}$ & $\begin{array}{l}0.2 \\
0.8\end{array}$ \\
\hline Амьжиргаагаа хөөж & 21.9 \\
\hline Эрүүл мэндийн шалтгаанаар & 3.3 \\
\hline Орон сууц-ахуйн нөхцөлийг дээшлүүлэх гээд & 8.5 \\
\hline Хамаатан садангийн хүмүүстэй ойр амьдрах & 12.7 \\
\hline Ажил хайж & 14.1 \\
\hline Ажлаа сольсон, дэвшсэн & 5.4 \\
\hline Мэргэжил эзэмшихээр, хүүхдээ сургахаар & 16.8 \\
\hline Сургууль төгссөний дараа хуваарилагдсан & 10.4 \\
\hline Гэрлэлт & 5.9 \\
\hline
\end{tabular}

Статистикийн судалгаанд үндэслэн тооцоход Монгол улсын хүн амын 45.7 хувь нь буюу 1.201.300 [5. 83] хүн Улаанбаатар хотод суурьшин амьдарч байна. Энэ нь Улаанбаатар хотын анхны төлөвлөлтөөс 1 дахин их хүн амьдарч байна.

Хот доторх орон зайн хуваарилалт

Сүүлийн жилүүдэд Улаанбаатар хотод хүн амын хэт төвлөрөлөөс үүдэлтэй хотын нийгэм, соёл, эдийн засаг, байгаль орчин, дэд бүтцийн хувьд шийдвэрлэвэл зохих шинэ шинэ асуудлууд урган гарах болсон. Хотод тодорхой хугацаанд амьдарч буй шилжин ирэгсэд болон уугуул оршин суугчид цэвэр агаартай, дуу чимээ бага г.м хотын аль тааламжтай газарт амьдрах сонирхолтой болсон. "Монгол дахь хотжих үйл явц" сэдэвт судалгааны үр дүнгийн урьдчилсан боловсруулалтаас харахад, хотын уугуул болон 1 жилээс дээш хугацаагаар амьдарч буй иргэд хотын дараах хэсгүүдэд амьдрах хүсэлтэй байна. 


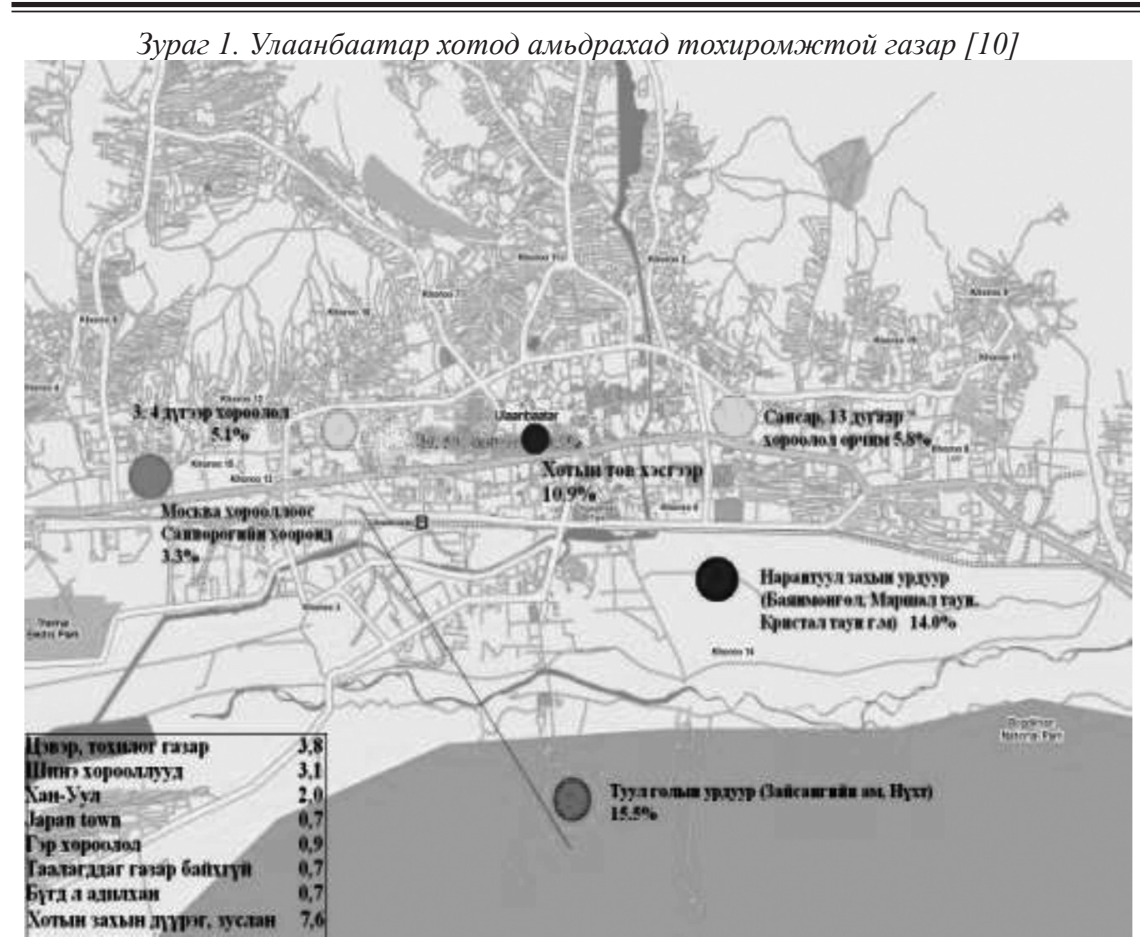

Тухайлбал, Энхтайвны гүүрнээс урагш шилжин ирэгсдийн 34.3 хувь нь хотын олон шинэ хороолол баригдаж байгаагаас Үүдэлтэй тус хэсгээс хотын төв рүҮ чиглэсэн замын ачаалал нэмэгдэх болсон. Харин төвд ойролцоо, 32.6 хувь нь захдуу газар, 22.2 хувь нь хотын төвд амьдарч байна. Тодруулбал,

График 2. Шилжин ирэгсдийн суурьшиж буй бүс

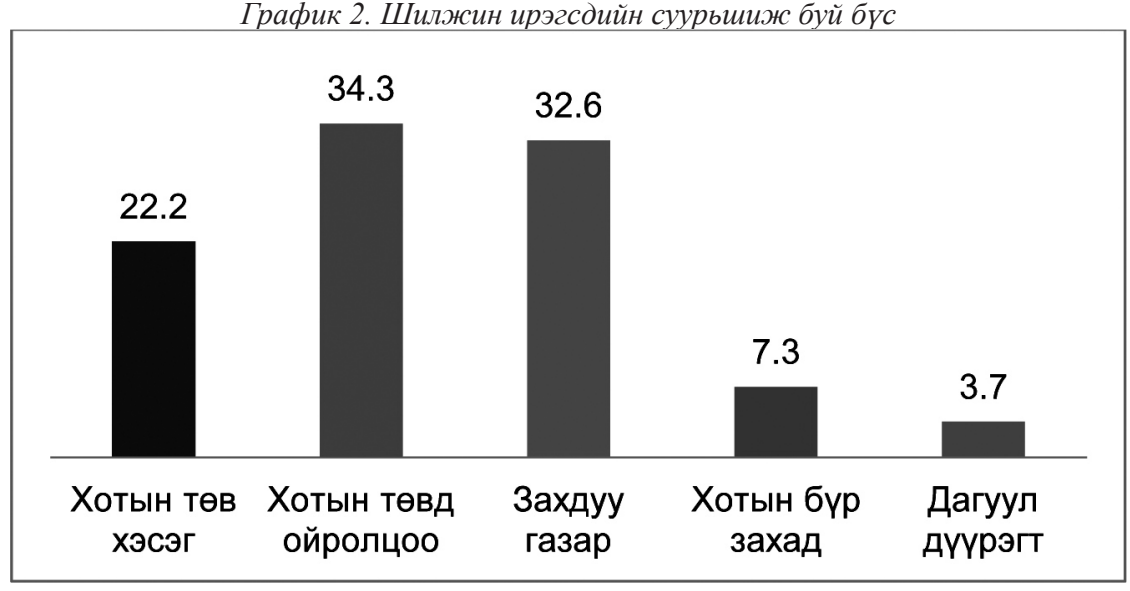

Бидний таамаглаж ярьдагчлан хотын хүн хотын төвд, байранд амьдардаг, хөдөөний хүн хотын захад гэр хороололд гэрт, эсвэл галладаг байшинд амьдардаг гэсэн ойлголт байхаа больж. Боломж бололцоотой бол тансаг хаус, байр сууцанд амьдрах эрх хүн бүрт нээлттэй болсон учир хүн боломж бололцооныхоо хэрээр суурьшлын бүс, орон байраа сонгодог болсон. Тодруулбал, хотынх, хөдөөнийх 
гэж ялгахад төвөгтэй сүлэгдмэл, заримдаг хэв маяг бий болох үндсэн хүчин зүйл болж байна. Үүнд орлогын түвшин ихээхэн нөлөөлж байгаа юм. Тухайлбал, хотжилтын судалгааны үр дүнгээс харахад орлогын түвшин нэмэгдэх тусам сууцны нөхцөл нь сайжирч, хотын төв хэсэгт орон сууцны хороололд суурьшиж байна.

ХУснэгт 4. Сууины хэв маяг, орлогын харьиуулсан ҮзүҮлэлт

\begin{tabular}{|lcccc} 
Хувийн тохилог хаус & $\begin{array}{c}\text { Орон } \\
\text { сууцанд }\end{array}$ & $\begin{array}{c}\text { Галлагаатай } \\
\text { байшинд }\end{array}$ & Гэрт \\
\hline 126500 хүртэл & 0.0 & 7.7 & 30.8 & 57.7 \\
$126501-379503$ & 1.5 & 25.4 & 41.0 & 26.3 \\
$379504-759006$ & 2.3 & 28.6 & 37.3 & 27.6 \\
$759007-1138510$ & 2.4 & 42.7 & 35.4 & 17.1 \\
$1138511-1518014$ & 4.5 & 70.8 & 14.6 & 5.6 \\
$11518015-1897518$ & 0.0 & 60.0 & 20.0 & 16.0 \\
$1897519-$-өс дээш & 12.5 & 66.3 & 12.5 & 6.3
\end{tabular}

Бага орлоготой иргэдийн хувьд тансаг, тохилог сууцанд амьдрах боломж хязгаарлагдмал тул гэр хороололд, эсвэл хотын зах руу төлөвлөгдөөгүй газар суурьшиж, хотыг газар нутгийн хувьд тэлэх байдал ажиглагдаж байна. Амьжиргааны түвшин өндөртэй айл өрхүүдэд зориулсан орон сууцны шинэ, тохилог хорооллууд хотын төв, хотын төвийн ойролцоо олноор баригдах болсон.

\section{Нэгэн судалгааны үр дүнд} тэмдэглэснээр, Улаанбаатар хотод 2003-
2007 оны хооронд орон сууц 1.8 хувиар, гэр хороолол 1.3 хувиар, барилгажсан талбай 5.9 хувиар, нийт хотожсон талбай 3.9 хувиар тус тус өссөн бол задгай талбайн хэмжээ 2 хувиар буурсан үзүүлэлттэй байгаа нь шилжин ирэгсэд хотын бүх хэсэгт жигд тархан суурьшиж байгааг харуулж буй нэг баримт юм. Мөн Улаанбаатар хотод орон зайн хувьд бөөгнөрөл бий болж байгааг харуулж байгаагаас гадна тэлэлт явагдаж байгааг харуулж байна.

График 3. Улаанбаатар хотын талбайн тэлэлт, хотжилтын график [9] (Харьиуулсан үр дүн)

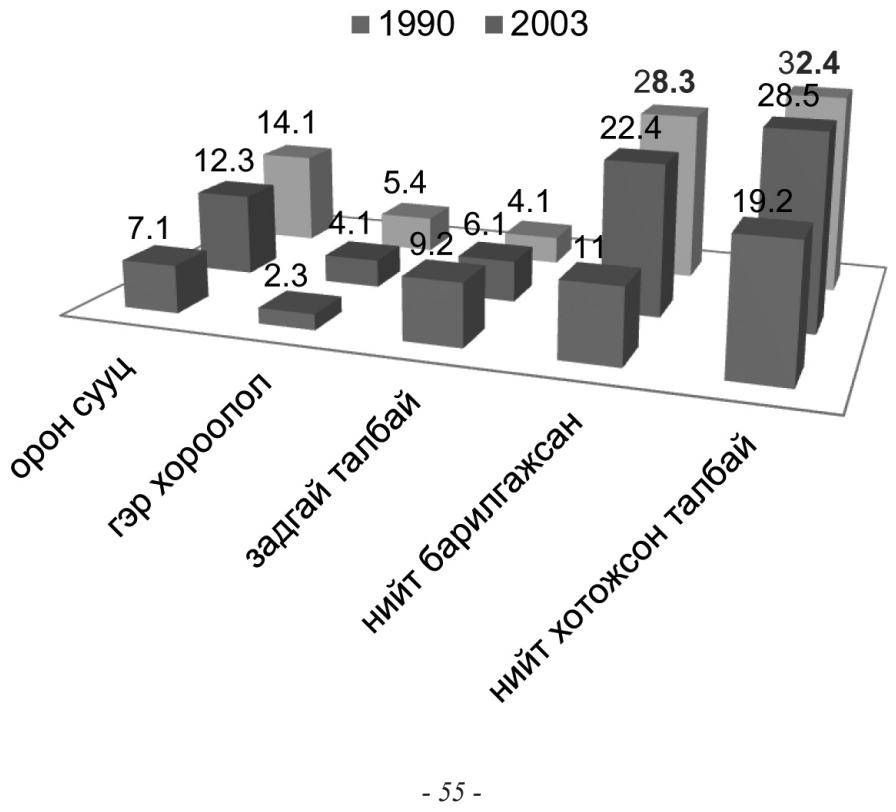


Дээрх үр дүнгээс харвал Улаанбаатар хотод шинээр суурьшигчид болон уугуул иргэдийн аль аль нь хотын төвийг тойрон суурьшиж байгаа бөгөөд энэ нь Улаанбаатар хотын талбайн тэлэлт, суурьшлын бүс,

\section{Тулгамдсан асуудал}

Орчны асуудал: Эрүүл мэнд, орчны нөхцөл байдлын талаарх судалгааны баримт материал нэлээд ноцтой дүгнэлтүүд хийсэн байдаг. Тухайлбал, "Хотжилт-эрүүл ахуй, экологийн асуудал” сэдэвт илтгэлд хотын орчны талаар “... хот суурингийн барилгажиж, суурьшсан эдэлбэр газрын 30-аас доошгүй хувийг зүлэгжүүлж ногоон байгууламжтайгаар ашиглах ёстой боловч эрүүл ахуй, экологийн энэхүҮ шаардлагыг хангасан хот суурин байхгүй байна. Улаанбаатар хотод ногоон байгууламжийн эзлэх талбай хотын эдэлбэр газрын дөнгөж 3 хүрэхгүй хувь, Дархан, Эрдэнэт, Чойбалсан хотуудад 3-7 хувь байна. Улаанбаатар хотод агаарын бохирдол жилээс жилд нэмэгдэж байна. Агаарын бохирдлыг хянах байнгын тандалтын судалгааны дүнгээс үзэхэд 2005 онд Улаанбаатар хотын агаарт хүхэрлэг хийн жилийн дундаж агууламж 13 мкг/м ${ }^{3}$ байсан бол 2010 онд 27 мкг/м ${ }^{3}$ болж агаарын чанарын стандарт MNS 4585:2007-д заасан үзүүлэлтээс 2.7 дахин, хоногийн дундаж агууламжаар 5 дахин хэтэрч байв. Азотын давхар ислийн жилийн дундаж агууламж 2005 онд 29 мкг/м³ байсан бол 2010 онд 35 мкг $/ \mathrm{M}^{3}$ болж зөвшөөрөгдөх дээд хэмжээнээс 1.2 дахин нэмэгдсэн байна. Сүүлийн жилүүдэд Улаанбаатар хотод өвлийн улирал, галлагааны үед түлшний шаталттай холбоотой утаа, химийн бохирдол ихэсч байхад дулааны улиралд газрын хөрс, гудамж талбайн тохижилтгүй орчноос тоосжилт ихэсч, $\mathrm{PM}_{10}, \mathrm{PM}_{2.5}$-ын тоосны хэмжээ ихэссэнээс уушгины хавдрын өвчлөлд нөлөөлж, хүҮхдийн гуурсан хоолойн иочмог, архаг үрэвсэлт өвчинд хотын агаар дахь тоос, хүхэрлэг хий, азотын ислүуд, угаарын хийн нөлөөлөл гол шалтгаан болж сонирхол зэргээс тодорхой харагдаж байгаа юм. ИйнхүҮ хотын төвийг тойрон суурьшиж байгаагаас үүдэлтэй дараах бэрхшээлүүд гарах болсон.

байгааг судлаачид тогтоосон байна" [11]. Доорх зурагт үзүүлсэнээс харвал Улаанбаатар хотын III, IV хороолол, 100 айлаас Дарь-Эх хүртэл, Цайз зах орчмоор агаарын бохирдлын хэмжээ хамгийн өндөр байдаг.

Агаарын түгээмэл бохирдуулагчдын эрүүл мэндэд ҮзҮүлэх нөлөөллийг авч үзвэл, хүхэрлэг хий $\left(\mathrm{SO}_{2}\right)$ нь амьсгалын замын хамгаалах тогтолцоог алдагдуулж, ханиалгах, нүд хорсгох шинж тэмдэг илэрч, багтраа болон уушигны өвчин үүсгэдэг байна. Нүүрстөрөгчийн дутуу исэл (СО) бол зүрхний шигдээс болон зүрхний бусад өвчлөл, багтраа өвчин Үүсгэх, хүчилтөрөгчийн солилцоог алдагдуулан эд эрхтэнд гэмтэл учруулах, дутуу төрөлт нэмэгдэх, хүмүүсийн ажлын чадвар буурах нөхцөл болдог. Азотын давхар исэл $\left(\mathrm{NO}_{2}\right)$ нь нүд, уушги, арьс, салст бүрхэвч, амьсгалын замын эд, эрхтнүүдийг гэмтээх, гуурсан хоолойн багтраа, уушгины хатгалгаa, томуу, томуу төст өвчин, зүрх судасны өвчлөл үүсэхэд шууд нөлөөлөхийн зэрэгцээ амьсгалын замын архаг өвчлөлийг нэмэгдүүлнэ. Том ширхэглэлт тоосонцор $\left(\mathrm{PM}_{10}\right)$ болон нарийн ширхэглэлт тоосонцор $\left(\mathrm{PM}_{2.5}\right)$ нь амьсгалын замын эмгэг, арьс, элэг, уушгины зэрэг хавдар, зүрх судасны эмгэг, төрөл бүрийн удамшлын эмгэг үүсгэхэд нөлөөлдөг. Хар тугалга $(\mathrm{Pb})$ бол төв мэдрэлийн тогтолцооны эмгэг, цус багадалт, жирэмсэн эх, хүүхдэд сөргөөр нөлөөлж хүний биеийн ясанд удаан хугацаагаар хуримтлагдана. Мөн хоолны дуршил буурах, бөөрний хавдар үүсгэх, дутуу төрөлт үүсгэх магадлалтай. Бенз-а-пирен нь $\left(\mathrm{C}_{20} \mathrm{H}_{12}\right)$ нь уушги, хоол боловсруулах замын хавдар ҮҮсгэнэ [4]. 


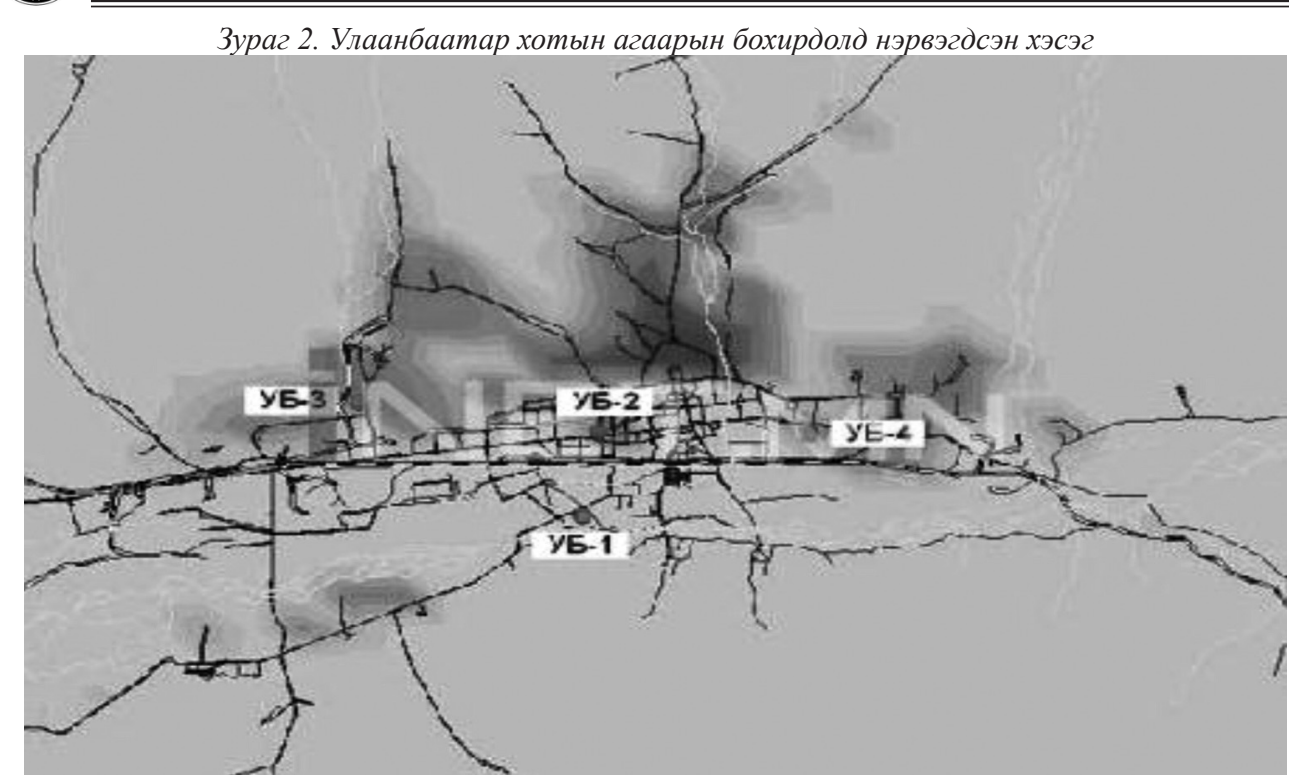

Дээрхээс гадна “ил задгай зөвшөөрөгдөөгүй газарт 65492м3 хэмжээний хог хаягдал хуримтлагдсан". "Хөрс нь өөртөө хорт бодисыг шингээж задлах чадавхи нь хэтэрсэн тохиолдолд газрын доорхи болон гадаргын ус ургамал, амьд организмыг хордуулж эхэлдэг. Тухайлбал, Судалт төвийн орчим хар тугалга зөвшөөрөгдөх хэмжээнээс 4-5 дахин их, Дэнжийн мянгын эх орчим цайр хүлцэх агууламжаас 8 дахин их байна.

Хайлаастын амны жалганд нянгын тоо зөвшөөрөгдөх хэмжээнээс 1239 дахин их болоод байгаа нь шинжилгээгээр нотлогдоод байна. Гэр хорооллуудын орчимд бохирдолтын үндсэн үзүүлэлт болдог нянгын тоо хотын дунжаас 2 дахин их байгаа нь гадаргын хог хаягдлаас үндсэндээ шалтгаалж байна. Хөрсний ерөнхий бохирдолтын түвшин Баянхошуу, Дэнжийн мянга, Амгалан, Шар хад, Хайлаастын ам, 100 айл зэрэг газруудад онцгой их буюу хотын дундаж агууламжаaс 10-16 дахин их” байгаа бол “1297 үйлдвэр аж ахуйн нэгж 7276 төрлийн 3774.8 тонн химийн бодисыг хэрэглэж, жил бүр агаарт 68, усанд 790, хөрсөнд 602 төрлийн 50 тонн химийн бодис хаягдаж, нийслэлд 560 тонн хатуу хог хаягдлаар ус, хөрс бохирдож, халдварт өвчлөлийн хэмжээ өсөн нэмэгдсээр" үндэсний аюулгүй байдалд” нөлөөлөх хандлагатай байна" [12] хэмээн дүгнэсэн нь Улаанбаатар хот дахь хэт төвлөрөлөөс ҮҮдэлтэй хор уршиг хэт их газар авсаныг илтгэнэ.

2005 онд ЭМЯ болон ДЭМБ-аас хамтран гаргасан "Усаар дамжих халдварт өвчний судалгаa”-ны дүнгээс харахад, Улаанбаатар хотын өрхийн ундны усны УСТ-992 стандарттай (1мл усанд байх нянгийн тоог 100-аас илүүгүй байх) харьцуулахад шинжилсэн 20 сорьцын нянгийн дундаж тоо 6424.6 \pm 2744.16 , хамгийн их нь 49000 байсан ажээ. Нийт сорьцын 75 хувьд нянгийн тоо өндөр, 80 хувьд гэдэсний бүлгийн болзолт эмгэг төрөгч нян илэрч, эрүүл ахуйн шаардлага хангахгүй дүн гарсан байна [12].

Хот суурингийн төлөвлөлт, байгуулалт, ашиглалтын эрүүл ахуйн шаардлага зөрчигдсөнөөс:

- ХҮн амын өвчлөл, нас баралт

- Амьсгал, зурх судасны иочмог, архаг эмгэг ҮУд

- Харшльн эмгэг

- Хорт хавдар

- Нөхөн үржихүйн эмгэг (дутуу, гажиг төрөлт) 
- Хоол боловсруулах системийн эмгэг

- ХҮҮхдийн бие бялдар, оюун сэтгэхуйн эмгэг

- ХХн амын дархлааны түвшин буурах гэХ мэт өвчин эмгэг, тус улсад сүүлийн жилүүдэд мэдэгдэхүйц нэмэгдэж байна гэж дүгнэсэн байдаг [11].

Орчны бохирдлоос үүдэлтэй эдгээр болон бусад асуудлын талаар иргэд дараах байр суурьтай байна.

График 4. Улаанбаатар хотын орчны бохирдлын талаарх олон нийтийн хандлага [9]

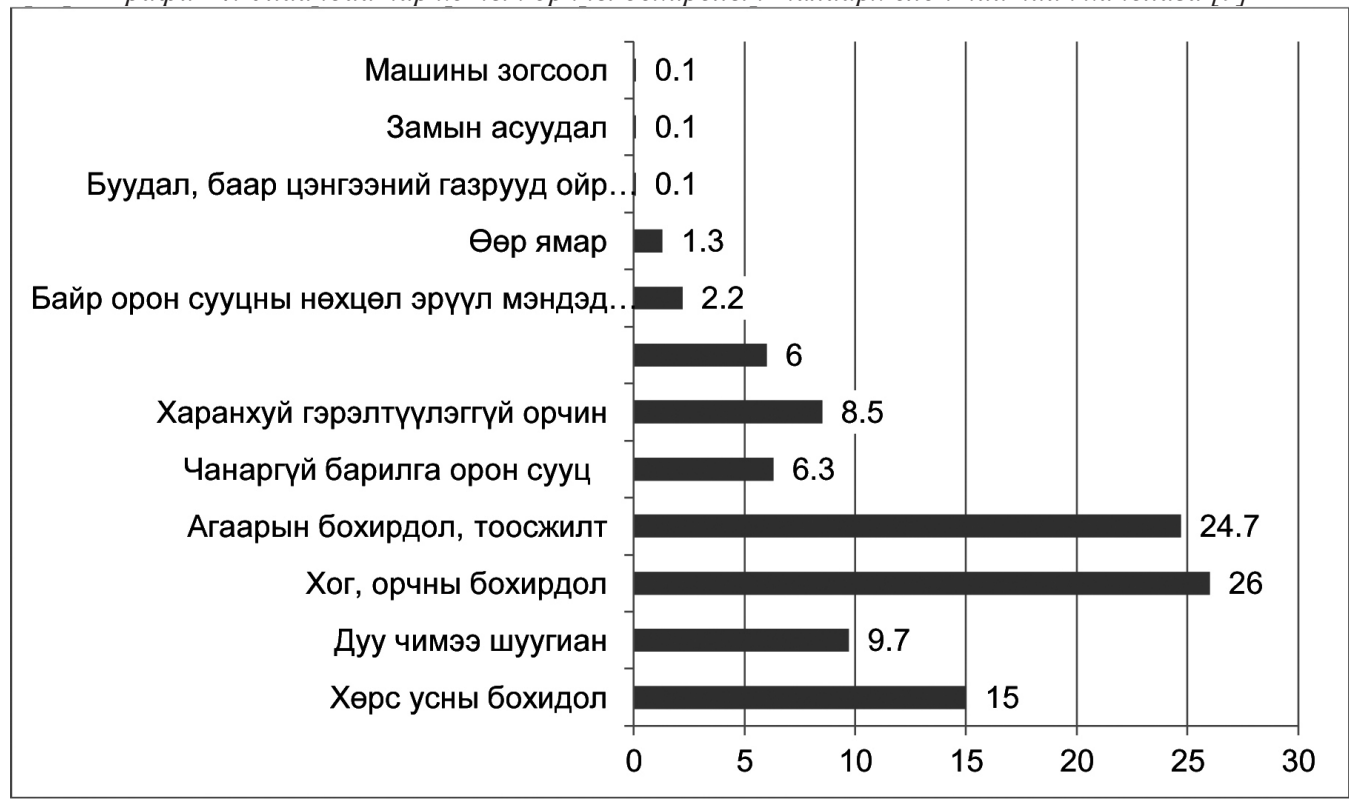

Соёл, харилиааны асуудал: Хотын хүн амын дунд хөдөөгийн иргэдийн эзлэх хувь нэмэгдэж хотын бүх хэсэгт График2-т үзүүлсэнчлэн жигд тархан суурьшиж байгаагаас Үүдэлтэй хот хөдөөгийн гэх ялгаа, амьдральнн хэв маяг бүдгэрэх болсон. Өнөөдөр хотын иргэдийн амьдрал, дүр төрх сумын төв, аймгийн төвд оршин сууж буй иргэдээс ялгагдахааргүй, заримдаг шинжтэй хэв маяг бий болж. Тухайлбал, Улаанбаатар дахь хотын захын хуучны орон сууц, гэр хороолол илэрхий хоцрогдсон, бохир заваан дүр төрхтэй байна. Хэт төвлөрөлийн үр дүнд хот ийм төрхийг олж байгаагийн дээр шилжин ирэгсдийн дунд хотожсон, хотын хэв маяг, ухамсарыг өөртөө төлөвшүүлсэн, нийтийн хэм хэмжээг ухамсарладаг хүн бага байна. Зарим талаар хотын уугуул гэх иргэдэд ч соёлч ухамсар дутагдалтай байдаг. Тухайлбал, ШУА-ийн ФСЭХ-ээс 2011 онд хийсэн судалгааны үр дүнгээс нэгтгэн харахад “судалгаанд оролцогчид хувь хүний соёл, төлөвшлийн асуудалд (49.3\%) нилээд шүүмжлэлтэй” хандаж байсан. Хотын иргэдийн дунд бий болж буй энэ асуудлыг дараах хүчин зүйлүүдээр тайлбарлаж болохоор дүр зураг ажиглагдаж байна.

Хотын уугуул иргэд хотын соёльг түгээх, таниулах гэхээс илүүтэй шилжин ирэгсдэд дургүйцсэн байдлаар хандах, шилжин ирэгсдийн соёл, хэв маяг давамгайлах хандлага илэрхий анзаарагддаг бөгөөд энэ байдалд үндэслэн зарим судлаачид "Хөдөөжсөн их хотын гамшиг” (Б.Доржгарди), “Хотжоогүй хөдөөний “дурак” (Баабар) гэж тодорхойлсон байдаг. Тодруулбал, уугуул иргэд болон шилжин ирэгсдийн хооронд соёлын зөрчил илэрч байна. Энэ нь зарим талаар Ф.Энгельсийн “Английн ажилчин ангийн байдал” бүтээлд 
“Бараг аливаа соёлт байдлын гадна өссөн, бага наснаасаа аливаа гачигдал зовлон үзэж дадсан, болхи бүдүүлэг архинд дуртай, өдөр шөнийг аргацааж өнгөрүүлдэг энэ хүмүүс Англид шилжин сууж, угаасаа боловсрол, нарийн зан суртахуунд бага хандлагатай английн хүн амын тэр давхраанд өөрсдийн бүдүүлэг дадал заншлыг нэвтрүүлж байна." [2] гэж тэмдэглэсэн байдаг бөгөөд энэХүY тодорхойлолттой дүйхүйц дүр зураг Улаанбаатар хотод ажиглагдах болсон.

Мөн дээрхийн зэрэгцээ хотод шинээр суурьшиж байгаа болон хотын уугуул иргэдийн дунд бие биеэ хардах, амиа бодох, хувиа хичээх үзэл газар авсан бөгөөд нийгмийн аль ч хэсгийнхэн энэ хандлагад тулгуурлан аливаад хандах болсон. Ийм үзэгдэл дан ганц Улаанбаатар хотодилрээгүй бөгөөд дэлхийн хотуудын түүхэнд өмнө нь тохиолдож байсан байна. Тухайлбал, Лондон хотын оршин суугчдын талаар 120иод жилийн өмнө “Зөвхөн хувийнхаа эрх ашгийг баримталж байгаа хүн бүрийн энэ үл хайхрагч хатуу сэтгэл, энэ хүйтэн цэвдэг, хөндий тасархай байдал нь ялангуяа бага газарт энэ бүх хүн бөөгнөрсний улмаас бүр ч гутамшигтай доромжлолтой юм. Хэдийгээр хувийнхаа эрх ашгийг бодсон энэ явцуу үзэл бол манай орчин үешйн нийгмийн үндсэн, түгээмэл зарчим мөн гэж бид мэдэж байгаа боловч эдгээр шинж байдал нь чухамхүу энд, том хотын чихцэлдээ, түлхэлцээнд илэрч байгаа шигээр хаана ч ийм илэрхий, нэр нүүргүй, эрс шууд илэрч байгаа газар байхгүй.” [2] гэж тэмдэглэсэн байдаг.

Иргэдийн соёлын хэм алдагдаж, хотын орчин нөхцөл илэрхий доройтсон явдал нотлох шаардлагагүй үнэн юм. Гол нь үүсээд буй нөхцөл байдлыг хэрхэн шийдвэрлэх асуудал чухалчлагдаж байгаа бөгөөд дараах саналыг дэвшүүлж байна.

Нэг: Хотын төв дэх татах хүчийг задлах буюу олон төвт бүсийг хөгжүүлэх.

Хоёр: Суурьшлын шинэ бүсүүдийг хөгжүүлэх үүднээс хотын хилийн гаднах дэд бүтцийн асуудлыг шийдвэрлэх (зам, дулаан, эрчим хүч г.м).

Гурав: Хотыг олон улсын туршлага, хотын хүн амын өсөлт, нийгмийн бүлгүүдийн орон зайн хувиарлалт зэрэг асуудлыг шинжлэх ухааны үндэстэй судалж хотыг дахин үр ашигтай төлөвлөх.

Дөрөв: УБ хотын татах хүчийг сааруулах үүднээс бүсийн хөгжлийг дэмжих.

\section{Аиигласан бүтээлийн жагсаалт}

1. Х.Гүндсамбуу. Монголын нийгмийн давхраажил: хөгжил хандлага ХХ. УБ.,2002.

2. Ф.Энгельс. “Английн ажилчин ангийн байдал”. Улсын хэвлэлийн газар. УБ.,1973.

3. J.JohnPalen. The urban sociology. $6^{\text {th }}$ edition. The McGraw-Hill Companies, Inc. NY., 2002. P 57.

4. “Монгол улсын хүний хөгжлийн илтгэл-2011”. Хотжилт, хотын өсөлтийн байгаль орчны асуудлууд. Уб., 2010.

5. МУҮСХ. Монгол улсын статистикийн эмхэтгэл-2011. УБ.,2012.

6. Хүн ам, орон сууцны 2000 оны улсын тооллого. УБ.,2001.

7. Хүн ам, орон сууцны 2010 оны улсын тооллого. УБ.,2011.

8. ШУА-ийн ФСЭЗХ. Монголын нийгмийн өөрчлөлт. УБ.,2008.

9. ШУА-ийн ФСЭХ-ийн Социлогийн сектор. "Нийгмийн адилсал, бүтцийн адилсал ба даяаршлын сорил” сэдэвт ОУ-ын эрдэм шинжилгээний бага хурал. Д.Энхболд. "Улаанбаатар хотын тулгамдсан асуудлууд иргэдийн үзэл хандлага" илтгэл. УБ.,2013.

10. ШУА-ийн ФСЭХ-ийн Социлогийн сектор. "Монгол дахь хотжих үйл явц: төлөв байдал, бэрхшээл хандлага" сэдэвт эрдэм шинжилгээний бага хурал. О.Баасантогтох. "Хотжих үйл явц ба суурьшил” (УБ.,2012) илтгэл. Тайлбар: “Монгол дахь хотжих үйл явц” суурь судалгааны ажлын урьдчилсан боловсруулалтын үр дүнг ашиглав.

11. ШУА-ийн ФСЭХ-ийн Социлогийн сектор. “Монгол дахь хотжих үйл явц: төлөв байдал, 
бэрхшээл хандлага" сэдэвт эрдэм шинжилгээний бага хурал. Н.Сайжаа, Ж.Купул, Ж.Хишигсүрэн. "Хотжилт-эрүүл ахуй, экологийн асуудал” сэдэвт илтгэл. УБ.,2012.10.16.

12. http://www.bodol.ikhzasag.mn/index.php/home/post/6 / "Улаанбаатар хотын экологи ба гамшгийн нөхцөл байдал судлах ажлын хэсгийн ахлагч Ш.Батмөнхийн дүгнэлтээс" ярилцлага 2010.04.21. 